\title{
Energy Performance Estimation of ASHRAE 90.1 App. G System 7 VAV with Reheat using Dynamic B-SIM
}

\author{
Norbert Harmathy ${ }^{1 *}$ \\ ${ }^{1}$ Budapest University of Technology and Economics, Faculty of Architecture, Department of Building \\ Energetics and Building Service Engineering, 1111 Budapest, Müegyetem rkp. 3, Hungary
}

\begin{abstract}
The research presents an energy strategy during the design process using advanced energy performance simulation technology. Team coordination and building performance efficiency during the design process is aided by con- ducting a performance based assessment with comprehensive fully incorporated design, construction, energy, HVAC and annual building operation. Perfor- mance based decision making is demonstrated through an office building com- plex. The engineering decisions were based on performance enhancement and overall energy demand reduction, which was evaluated on an annual basis. The building envelope's dominant curtain wall system was analyzed in detail in or- der to demonstrate qualitative energy performance improvement. ASHRAE 90.1 App. G System 7 VAV with reheat HVAC's annual energy performance was estimated and evaluated from the aspect of end-use energy which is usually the baseline system for achieving LEED energy performance credits.
\end{abstract}

\section{Introduction}

The investigation covers the energetic and operational energy demand analysis of a 23 205 sqm office building complex [1]. Operational energy demands and HVAC system operation were analyzed in detail using complex input datasets: climatic database, building structure, thermal loads, occupancy and HVAC system documentation. Vari- ous design alternatives were used to select the most preferable curtain-wall structure.

The calculations were performed with detailed dynamic energy simulation in EnergyPlus [2] engine. Our previous investigations were performed on existing buildings and their energy refurbishment processes [3-5]. Teams have demonstrated various approaches in energy analysis of office buildings using simulation techniques [6-8].

Our first task was to justify which curtain-wall window structure would be the most preferable from the energy performance aspect, and to demonstrate which is the most appropriate window type contributing to higher energy efficiency of the build- ing.

* Corresponding author: harmathy@egt.bme.hu 
During the investigation according to the buildings geometry the massing of the building contributed significantly to its energy performance.

We evaluated the influence of the curtain-wall structure on the heating and cooling energy requirements on an annual basis, from which we determined the annual energy savings.

The report includes the results of selecting the right facade glass structure that meets the energy and cost optimum requirements. The ASHRAE 90.1 VAV system was simulated in order to assess and evaluate its annual end use energy consumption in order to help decision-making in the early design phases of the energy strategy.

The VAV systems energy performance will form the baseline minimum requirement compared to which the project has to perform better.

\section{Research focus and methodology}

During the energy performance analysis, we focused on the following:

- Building simulation and determination of energy demands

- Determining detailed heating and cooling energy requirements

- Analysis of thermal load alternatives

- Influence of internal heat loads on the annual energy balance

- Determining the energy influence of the glass structure annually

- Analyzing the effect of different curtain wall systems' thermal properties

- HVAC system simulation and end use energy determination of the project

- Total energy consumption potential

The virtual environment was created in EnergyPlus software where the simulation was performed according to the calculation models from the EnergyPlus Engineering documentation [9].

The geometric thermal model was created in Sketchup [10] and the data were imported in OpenStudio [11] software.

\section{Dynamic simulation input parameters}

\subsection{Weather data - climatological data sets.}

The climatic data was used from the Meteonorm [12] Swiss global database. The meteorological data package for Budapest contained more than 100,000 data.

In the simulation process 30 year hourly averages were applied. In the dynamic simulation we used the following climatic data; air temperature, relative humidity, direct and indirect solar radiation, pressure, wind direction and wind speed.

The weather data for Budapest were used from the data packages of ASHRAE Climate Design Conditions [13] which are shown in Table 1.

Depending on the size and complexity of the building, we divided the model into 22 thermal zones. The energy zone allocation by area and volume is shown in Table 2. 
Table 1. Weather file for BUDAORS, HUNGARY (WMO: 128380) from ASHRAE Climate Design Conditions

\begin{tabular}{|c|c|c|c|c|c|c|c|c|c|c|c|c|c|c|c|}
\hline \multicolumn{2}{|c|}{ Lat: $47.45 \mathrm{~N}$} & \multicolumn{2}{|c|}{ Long:18.97E } & \multicolumn{2}{|c|}{ Elev:132 } & \multicolumn{3}{|c|}{ StdP: 99.75} & \multicolumn{3}{|c|}{ Time zone: 1.00} & \multicolumn{4}{|c|}{ Period:82-92 } \\
\hline \multicolumn{16}{|c|}{ Annual Heating and Humidification Design Conditions } \\
\hline \multirow{3}{*}{\begin{tabular}{|c|} 
Col- \\
dest \\
Month
\end{tabular}} & \multirow{2}{*}{\multicolumn{2}{|c|}{ Heating DB }} & \multicolumn{6}{|c|}{ Humidification DP/MCDB and $\mathrm{HR}$} & \multicolumn{4}{|c|}{ Coldest month WS/MCDB } & \multirow{2}{*}{\multicolumn{2}{|c|}{$\begin{array}{l}\text { MCWS/PCWD } \\
\text { to } 99.6 \% \text { DB }\end{array}$}} & \\
\hline & & & \multicolumn{3}{|c|}{$99.6 \%$} & \multicolumn{3}{|c|}{$99 \%$} & \multicolumn{2}{|c|}{$0.4 \%$} & \multicolumn{2}{|c|}{$1 \%$} & & & \\
\hline & $99.6 \%$ & $99 \%$ & DP & HR & MCD B & DP & HR & MCD B & WS & MCD B & WS & MCD B & MCWS & PCWD & \\
\hline 1 & -11.2 & -9.0 & -14.4 & 1.1 & -9.8 & -12.3 & 1.3 & -7.3 & 18.0 & -0.9 & 16.6 & 0.7 & 1.9 & 270 & \\
\hline \multirow{4}{*}{\begin{tabular}{|c|} 
Hot- \\
test \\
Month
\end{tabular}} & \multicolumn{15}{|c|}{ Annual Cooling, Dehumidification, and Enthalpy Design Conditions } \\
\hline & \multirow{3}{*}{$\begin{array}{l}\text { Hottest Month } \\
\text { DB Ran ge }\end{array}$} & \multicolumn{6}{|c|}{ Cooling DB/MCWB } & \multicolumn{6}{|c|}{ Evaporation WB/MCDB } & \multirow{2}{*}{\multicolumn{2}{|c|}{$\begin{array}{c}\text { MCWS/PCWD t } \\
0.4 \% \text { DB }\end{array}$}} \\
\hline & & \multicolumn{2}{|c|}{$0.4 \%$} & & $1 \%$ & & $2 \%$ & 0. & $4 \%$ & 1 & $\%$ & 2 & $\%$ & & \\
\hline & & DB & MCWB & DB & $\underset{\mathrm{B}}{\mathrm{MCW}}$ & DB & MCW B & WB & MCD B & WB & MCD B & WB & MCDB & MCWS & PCWD \\
\hline 7 & 10.3 & 31.0 & 20.1 & 29.3 & 19.7 & 27.8 & 19.2 & 21.3 & 28.9 & 20.5 & 27.5 & 19.8 & 26.1 & 2.9 & 180 \\
\hline & & Dehumidi & fication DF & P/MCD & $\mathrm{B}$ and $\mathrm{H}$ & & & & & & Enthalp & $\mathrm{y} / \mathrm{MCDB}$ & & & Hours 8 \\
\hline & $0.4 \%$ & & & $1 \%$ & & & $2 \%$ & & 0.4 & $4 \%$ & & $1 \%$ & $2^{\circ}$ & & $12.8 / 20$. \\
\hline DP & HR & MCDB & DP & HR & MCD B & DP & HR & MCD B & Enth & MCD B & Enth & MCD B & Enth & $\mathrm{MCDB}$ & \\
\hline 18.6 & 13.7 & 24.3 & 17.9 & 13.1 & 23.6 & 17.3 & 12.5 & 23.0 & 62.1 & 28.9 & 59.4 & 27.9 & 56.9 & 26.1 & 923 \\
\hline & & & & & Ext & treme A & innual De & sign Con & nditions & & & & & & \\
\hline & & & & & Extreme & Annual & DB & & $\mathrm{n}-\mathrm{Yc}$ & ear Retur & in Period & d Values o & of Extrem & ne DB & \\
\hline & xtreme Annual & WS & Max W B & & Mean & Stanc & $\begin{array}{l}\text { d.deviati } \\
\text { on }\end{array}$ & $\mathrm{n}=5$ & years & $\mathrm{n}=10$ & years & $\mathrm{n}=20$ & years & $\mathrm{n}=5 \mathrm{c}$ & 0 years \\
\hline $1 \%$ & $2.5 \%$ & $5 \%$ & & Min & $\operatorname{Max}$ & Min & Max & Min & $\operatorname{Max}$ & Min & $\operatorname{Max}$ & Min & $\operatorname{Max}$ & Min & $\operatorname{Max}$ \\
\hline 13.9 & 11.6 & 9.3 & 24.3 & -16.3 & 33.5 & 5.1 & 1.4 & -19.9 & 34.5 & -22.9 & 35.3 & -25.8 & 36.1 & -29.4 & 37.1 \\
\hline Monthly & Climatic Desig & gn Conditi & & & & & & & & & & & & & \\
\hline & & & Annual & Jan & Feb & Mar & Apr & May & Jun & Jul & Aug & Sep & Oct & Nov & Dec \\
\hline & & Tavg & 10.6 & $\mid-0.3$ & 1.0 & 5.6 & 11.2 & 16.2 & 18.2 & 21.1 & 20.5 & 16.9 & 10.7 & 4.0 & 1.5 \\
\hline & & $\mathrm{Sd}$ & & 4.86 & 4.66 & 4.47 & 3.47 & 3.27 & 3.04 & 2.99 & 3.20 & 3.06 & 3.98 & 3.79 & 4.18 \\
\hline & & $\begin{array}{c}\text { HDD10. } \\
0\end{array}$ & 1236 & 319 & 253 & 147 & 27 & 2 & 0 & 0 & 0 & 1 & 38 & 182 & 266 \\
\hline & & $\begin{array}{c}\text { HDD18. } \\
3\end{array}$ & 3072 & 577 & 486 & 396 & 216 & 81 & 38 & 9 & 16 & 64 & 236 & 431 & 523 \\
\hline & & $\begin{array}{c}\text { CDD10. } \\
0\end{array}$ & 1452 & 0 & 1 & 9 & 62 & 193 & 247 & 344 & 326 & 206 & 62 & 2 & 1 \\
\hline $\begin{array}{r}\text { Temper: } \\
\text { Days }\end{array}$ & $\begin{array}{l}\text { atures, Degree- } \\
\text { and Degree- }\end{array}$ & $\begin{array}{c}\text { CDD18. } \\
3\end{array}$ & 246 & 0 & 0 & 0 & 1 & 13 & 34 & 95 & 83 & 19 & 0 & 0 & 0 \\
\hline & & $\begin{array}{c}\mathrm{CDH} 23 . \\
3\end{array}$ & 2089 & 0 & 0 & 0 & 4 & 101 & 276 & 860 & 698 & 149 & 2 & 0 & 0 \\
\hline & & $\begin{array}{c}\mathrm{CDH} 26 . \\
7\end{array}$ & 573 & 0 & 0 & 0 & 0 & 14 & 55 & 272 & 211 & 22 & 0 & 0 & 0 \\
\hline & & & DB & 10.5 & 16.3 & 21.3 & 24.3 & 28.8 & 30.3 & 33.2 & 32.4 & 29.3 & 23.1 & 15.5 & 14.4 \\
\hline & & $0.4 \%$ & MCWB & 7.0 & 10.2 & 13.0 & 15.3 & 17.7 & 20.2 & 20.3 & 20.5 & 19.2 & 16.1 & 11.6 & 10.8 \\
\hline Month & ly Design Dry & & DB & 8.6 & 12.0 & 17.0 & 21.7 & 25.9 & 28.2 & 31.4 & 30.8 & 26.9 & 20.9 & 12.0 & 11.2 \\
\hline Bulb an & id Mean Coin- & $2 \%$ & MCWB & 6.3 & 7.9 & 10.6 & 13.7 & 17.1 & 20.1 & 20.5 & 19.7 & 18.1 & 15.2 & 9.2 & 8.8 \\
\hline & nperatures & & DB & 7.4 & 8.8 & 14.6 & 19.6 & 24.1 & 26.4 & 29.7 & 29.1 & 25.1 & 18.8 & 10.3 & 9.1 \\
\hline & & $5 \%$ & MCWB & 5.4 & 5.7 & 9.5 & 13.0 & 16.7 & 18.9 & 20.0 & 19.5 & 17.8 & 13.6 & 8.1 & 6.9 \\
\hline
\end{tabular}




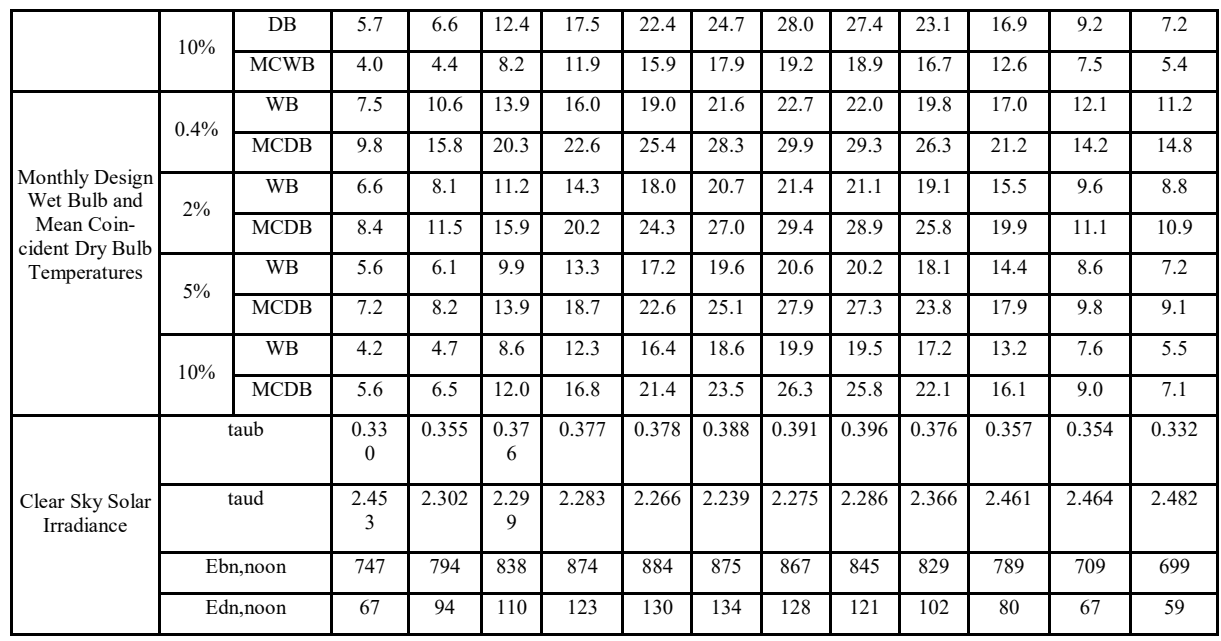

Table 2. Thermal zoning with area and volume

\begin{tabular}{|l|l|l|l|}
\hline Thermal zone & Area [m2] & Volume [m3] \\
\hline 1 & Open Office North 0 & 1425.15 & 6595.03 \\
\hline 2 & Open Office North 2 & 1278.78 & 3580.57 \\
\hline 3 & Open Office North 3 & 1278.78 & 3580.57 \\
\hline 4 & Open Office North 4 & 1155.29 & 3234.81 \\
\hline 5 & Open Office North 5 & 1161.40 & 3251.92 \\
\hline 6 & Open Office North 6 & 1161.40 & 3251.92 \\
\hline 7 & Open Office South 0 & 1576.57 & 6936.89 \\
\hline 8 & Open Office South 1 & 3402.77 & 10208.32 \\
\hline 9 & Open Office South 2 & 1432.48 & 4010.94 \\
\hline 10 & Open Office South 3 & 1432.48 & 4010.94 \\
\hline 11 & Open Office South 4 & 1432.48 & 4010.94 \\
\hline 12 & Open Office South 5 & 1519.52 & 4254.66 \\
\hline 13 & Open Office South 6 & 1519.52 & 4653.65 \\
\hline 14 & Open Office South 7 & 690.57 & 2386.66 \\
\hline 15 & Sanitary \& Communication 0 & 390.75 & 1904.55 \\
\hline 16 & Sanitary \& Communication 1 & 317.60 & 952.80 \\
\hline 17 & Sanitary \& Communication 2 & 379.35 & 1062.18 \\
\hline 18 & Sanitary \& Communication 3 & 379.35 & 1062.18 \\
\hline 19 & Sanitary \& Communication 4 & 379.35 & 1062.18 \\
\hline 20 & Sanitary \& Communication 5 & 379.35 & 1062.18 \\
\hline 21 & Sanitary \& Communication 6 & 379.35 & 1062.18 \\
\hline 22 & Sanitary \& Communication 7 & 132.30 & 370.44 \\
\hline & Total & 23204.57 & 72506.51 \\
\hline & & & \\
\hline
\end{tabular}

\subsection{Building envelope and curtain-wall thermal properties}


The building structure and layers were used in the thermal simulation according to the design and construction documentation. The objective was to analyze and simulate the building envelope's dual pane glass construction on the annual building energy performance. The building envelope's glass structure consisted of three glass structure types of which all are Argon filled, where under glazing A1 two different glass struc- tures are applied according to project documentation:

1. Glazing A1; U-Factor $=1.40 \mathrm{~W} / \mathrm{m} 2 \mathrm{~K}$, SHGC1 $=0.4, \mathrm{SHGC} 2=0.3$, Glass Visible Transmittance $1=0.70$ with inner pane shading and Argon gas (Southern facade), Glass Visible Transmittance $2=0.70$ without inner pane shading.

2. Glazing A2; U-Factor $=1.40 \mathrm{~W} / \mathrm{m} 2 \mathrm{~K}, \mathrm{SHGC}=0.5$, Glass Visible Transmittance $=0.73$ (East and West orientation)

3. Glazing A3; U-Factor $=1.40 \mathrm{~W} / \mathrm{m} 2 \mathrm{~K}, \mathrm{SHGC}=0.6$, Glass Visible Transmittance $=0.80$ (North orientation)

The focus was on the structural and energetic performance of the facade glazing. The use of adequate glazing is of utmost importance for efficient energy reduction and user comfort. Choosing the right glass structure depends from; building's type and function, the building floor area, window to wall ratio, facade orientation, internal heat loads, building location and climate zone. The listed parameters all affect the efficiency of the glass structure, building on the energy of the building. We investi- gated the influence of the heat transfer factor $(\mathrm{U})$, the solar factor $(\mathrm{g})$ and the light transmission factor $(\tau)$ on the yearly energy requirements and user comfort of the building. The title is set in bold 16-point Arial, justified. The first letter of the title should be capitalised with the rest in lower case. You should leave $22 \mathrm{~mm}$ of space above the title and $6 \mathrm{~mm}$ after the title.

\subsection{Thermal comfort demand and building operation data}

The energy simulation allows detailed analysis of building operation according to schedules. Its significance lies in the fact that we can investigate the energy and heat loads of a building according to various time dependant scenarios. With energy simu- lation, we calculated the building's energy demand annually using the following data:

Heating period (indoor air temperature):

Minimum indoor air temperature was $20^{\circ} \mathrm{C}$ during permanently occupied periods. Outside working hours the maximum allowed temperature fall was $4^{\circ} \mathrm{C}$. The heating system operates with an automatic indoor air temperature sensor setting.

Cooling period (indoor air temperature):

Maximum indoor air temperature was $26^{\circ} \mathrm{C}$ during permanently occupied peri- ods. Outside working hours the cooling system is not operating. The cooling sys- tem operates with an automatic indoor air temperature sensor setting.

In both periods, the perimeter values of air temperatures were maintained daily in 10 hour intervals (8-18h). In case changes in occupancy schedules of the building, number of people and work hours, the energy demands will change. The results of the energy simulation apply only to the specified 10 hours working time and to the perimeter values of the specified air temperature. Air change rate and specified air vol- ume in thermal zones was calculated according to equation 1 where $\mathrm{n}$ is the number of people and $\mathrm{A}$ is the area in $\mathrm{m} 2$.

$$
\text { qtot }=\mathrm{n} \times 25,2+\mathrm{A} \times 2,52
$$

qtot $=2520 \times 25,2+21400 \times 2,52$

qtot $=117432 \mathrm{~m} 3 / \mathrm{h}$ 
For the office spaces 0.46 ach was assumed. In the simulation we counted $0.81 / \mathrm{h}$ air change was the maximum intensity during working hours. During unoccupied periods the air change rate was $0.11 / \mathrm{h}$. The intensity of air exchange depends on working time. From 7 to 18 hours constant air volume was estimated.

\section{Energy performance results}

\subsection{Annual energy demands for heating and cooling}

With the energy simulation run-time of 8760 hours annual heating and cooling en- ergy demands were determined for two operational scenarios:

Permanent maximum heat loads - entire building is occupied during working hours

Without internal heat loads - estimation of internal loads influence on the ener- gy performance. Particular emphasis was placed on the curtain wall's glass structure and its energy performance. The heating and cooling energy requirements with different grazing types from the simulations are shown in Table 3. The energy demands were classified according to the parameters of the facade glass structure. Table 4 shows the percent- age deviation of the aggregate annual energy demand.

Table 3. Annual energy demands for heating and cooling

\begin{tabular}{|c|c|c|c|c|}
\hline $\begin{array}{l}\text { Curtain wall glazing } \\
\text { properties }\end{array}$ & $\begin{array}{l}\text { Heating } \\
{[\mathrm{MWh} / \mathrm{a}]}\end{array}$ & $\begin{array}{l}\text { Cooling } \\
{[\mathrm{MWh} / \mathrm{a}]}\end{array}$ & $\begin{array}{l}\text { Heating per m2 } \\
{[\mathrm{MWh} / \mathrm{m} 2 / \mathrm{a}]}\end{array}$ & $\begin{array}{l}\text { Cooling per m2 } \\
{[\mathrm{MWh} / \mathrm{m} 2 / \mathrm{a}]}\end{array}$ \\
\hline \multicolumn{5}{|c|}{ With constant maximum internal heat loads } \\
\hline $\mathrm{A} 1 \mathrm{~g} 1=0,4 ; \mathrm{g} 2=0,3$ & 1228 & 658 & 53 & 28 \\
\hline A2 $g=0,5$ & 1184 & 800 & 51 & 34 \\
\hline $\mathrm{A} 3 \mathrm{~g}=0,6$ & 1151 & 941 & 49 & 40 \\
\hline \multicolumn{5}{|c|}{ Without internal heat loads } \\
\hline $\mathrm{A} 1 \mathrm{~g} 1=0,4 ; \mathrm{g} 2=0,3$ & 1557 & 60 & 67 & 3 \\
\hline $\mathrm{A} 2 \mathrm{~g}=0,5$ & 1475 & 138 & 63 & 6 \\
\hline A3 $g=0,6$ & 1415 & 228 & 61 & 10 \\
\hline
\end{tabular}

Table 4. Annual energy demands proportional deviation

\begin{tabular}{|l|l|l|l|}
\hline & Total energy [MWh/a] & Percentual reduction [\%] & Reduced energy [MWh/a] \\
\hline A1 & 1886 & $\begin{array}{l}9,8 \% \text { according to A3 } \\
5 \% \text { according to A2 }\end{array}$ & 206 \\
& & $5 \%$ \\
\hline A2 & 1984 & $0 \%$ & 0 \\
\hline A3 & 2092 & $5 \%$ according to A3 & 108 \\
\hline
\end{tabular}

\subsection{ASHRAE VAV with reheat energy performance simulation}

Following the heating and cooling demand assessment according to adequate glazing assignment of the Variable air volume (VAV) HVAC systems was simulated in order to assess their annual operating performance. The following table 5 shows the end energy uses for the VAV System with reheat and table 6 shows the annual electricity consumption of interior lighting and equipment.

Table 5. Annual end energy uses per category for VAV system

\begin{tabular}{|l|l|l|l|l|}
\hline Category & Electricity [GJ] & Electricity [kWh] & Gas [GJ] & Water [m3] \\
\hline Heating & - & - & 4843.80 & - \\
\hline
\end{tabular}




\begin{tabular}{|l|l|l|l|l|}
\hline Cooling & 859.74 & 238816 & - & - \\
\hline Fans & 451.20 & 125333 & - & - \\
\hline Pumps & 724.35 & 201208 & - & - \\
\hline Heat Rejection & 25.27 & 7019 & - & 3864.90 \\
\hline Total End Uses & 2060.55 & 572375 & 4843.80 & 3864.90 \\
\hline
\end{tabular}

Table 6. Annual end uses per interior lighting and equipment in GJ an $\mathrm{kWh}$

\begin{tabular}{|l|l|l|}
\hline Category & Electricity $[\mathrm{GJ}]$ & Electricity $[\mathrm{kWh}]$ \\
\hline Interior Lighting & 2226.45 & 618458 \\
\hline Interior Equipment & 2931.12 & 814200 \\
\hline
\end{tabular}

Proportional presentation of the total annual energy consumption for each energy consumer per category is shown in figure 1 .

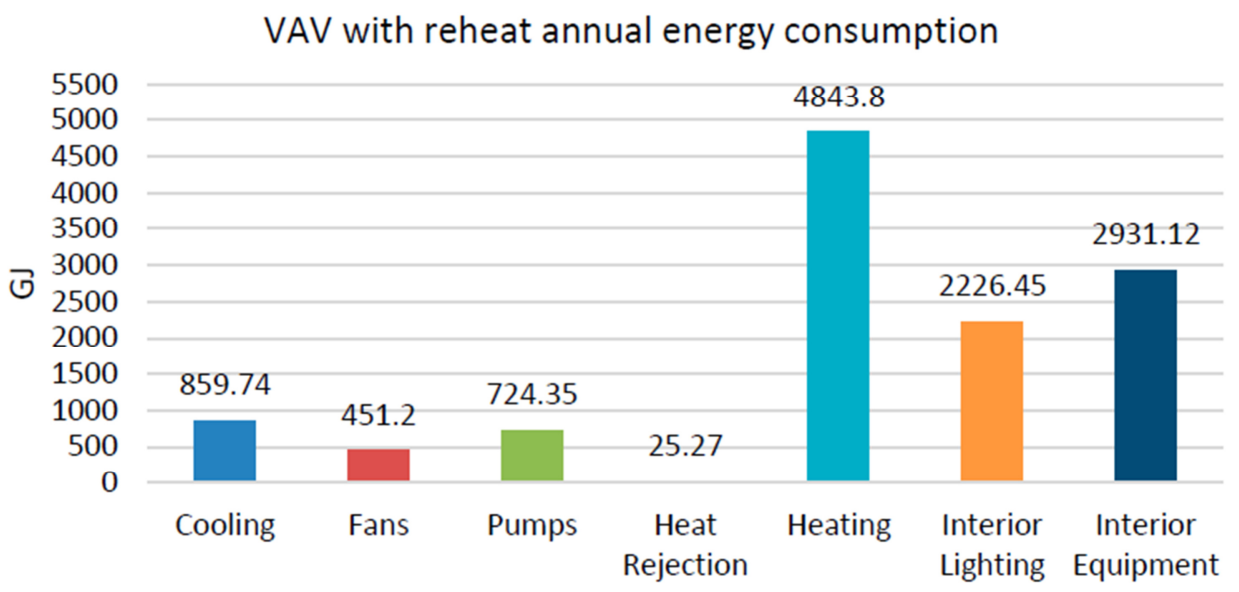

Fig. 1. VAV system annual energy consumption by category

The findings indicated that the highest energy consumption was demonstrated for the heating, supplied by natural gas. All other categories have electricity supply so if converted into primary energy these proportions will change and reflect completely different results. According to the Hungarian primary energy conversion factor for electricity is 2.5 and natural gas is 1.0 [14]. The results for primary energy consumption are shown in table 7.

Table 7. Primary energy consumption of system

\begin{tabular}{|l|l|}
\hline Source-use & Primary energy $[\mathrm{MWh}]$ \\
\hline Electricity total & 5012.58 \\
\hline Gas total & 1345.55 \\
\hline
\end{tabular}

\section{Conclusion}

The investigation presented that the energy demand could be influenced by the selection of adequate glazing type which can be determined by analysing the curtain wall's influence on the total energy demand as function dependant. Findings indicated that for an office building with high internal heat gains can lower its heating demands by selecting glazing in wider SHGC interval from 0.3 to 0.6 . The changes between the total energy demand (heating and cooling) scenarios for the three simulated glazing types was max. $9,8 \%$ on 
annual basis. However, investment in glazing with more efficient low-E layers is higher. Nevertheless, cooling should be taken in account seriously since the deviation was $30 \%$. It was concluded that high energy reduction can be achieved according to the HVAC system operation, the electricity end energy use for the VAV system resulted with $2060 \mathrm{GJ} / \mathrm{a}$ (572 $\mathrm{MWh}$ ) electricity and $4843 \mathrm{GJ} / \mathrm{a}(1345 \mathrm{MWh})$ for heating. Conversion into source consumption demonstrated different results the total primary electric energy for HVAC including lighting and equipment was 3,7 times higher compared to the gas primary energy. Further investigations will evaluate the energy performance of more efficient HVAC system as VRF system, air source heat pump, packaged terminal units, fan coils, geothermal source etc. The baseline performance should inform the designers which should be the necessary measures needed to be undertaken for overall building performance.

\section{Acknowledgement}

The research reported in this paper was supported by the Higher Education Excellence Program of the Ministry of Human Capacities in the frame of Artificial Intelligence research area of Budapest University of Technology and Economics (BME FIKP-MI/SC).

\section{References}

1. Szerdahelyi, L.: Office Building Project Documentation. Aspectus Architect Ltd. 2018. Budapest. Hungary

2. EnergyPlus, https://energyplus.net/ accessed 2018

3. Harmathy, N., Murgul, V.: Heat Pump System Simulation towards Energy Performance Estimation in Office Buildings. Procedia Engineering 165, (2016) 10.1016/j.proeng.2016.11.932.

4. Harmati N, Folić R, Magyar Z, Dražić J, Kurtović-Folić N. Building envelope influence on the annual energy performance in office buildings. Thermal Science 20:(2). (2016) pp. 679-693. doi: 10.2298/TSCI141111109H

5. Harmathy N, Magyar Z, Folic R. Multi-criterion optimization of building envelope in the function of indoor illumination quality towards overall energy performance improvement. Energy 144. (2016) pp. 302-317. doi: 10.1016/j.energy.2016.07.162

6. Evins, R. Multi-level optimization of building design, energy system sizing and operation. Energy 90. 2015: pp. 1775-1789. doi: 10.1016/j.energy.2015.07.007

7. Krstić-Furundžić A., Kosić T. Assessment of energy and environmental performance of office building models: A case study, Energy and Buildings, (2015) 10.1016/j.enbuild.2015.06.050

8. Capeluto I.G., Ochoa C.E. Simulation-based method to determine climatic energy strate- gies of an adaptable building retrofit façade system. Energy 76, (2014) pp. 375384. Doi: 10.1016/j.energy.2014.08.028

9. EnergyPlus Engineering Reference, version 8.0 documentation, accessed 2018 https://energyplus.net/sites/all/modules/custom/nrel_custom/pdfs/pdfs_v8.8.0/Enginee ring Reference.pdf

10. Sketchup, https://www.sketchup.com/ accessed 2017

11. OpenStudio, http://nrel.github.io/OpenStudio-user-documentation/ accessed 2017

12. Meteonorm, http://www.meteonorm.com/ accessed 2015

13. ASHRAE Climate Design Conditions, http://ashrae-meteo.info/ accessed 2018 
14. TNM 7/2006 energy efficiency regulation homepage:

https://net.jogtar.hu/jogszabaly?docid=A0600007.TNM/ accessed 2019 